DOI https://doi.org/10.18551/rjoas.2018-01.13

\title{
THE IMPACT OF THE FIRST GENERATION LEADERSHIP IN THE HUMAN RESOURCES LOYALTY GROWTH OF PT. KPA SURABAYA
}

\author{
Indradewi A.A.* ${ }^{*}$ Nirbito J.G. \\ Master of Management Program, Faculty of Management and Business, \\ University of Ciputra, Surabaya, Indonesia \\ *E-mail: astridathina@hotmail.com
}

\begin{abstract}
The objectives of research are: to know and to analyze the first generation leadership style; to know and to analyze the advantages and disadvantages of the first generation leadership; and to know and to analyze the impact of the first generation in the growth of human resource loyalty. This research used qualitative approach. Leadership style of (Late) $\mathrm{SHH}$ is a combination of Transformational Leadership Style, Entrepreneurship Leadership Style, and Authoritarian Leadership Style. In SHH's personality, who is strict and authoritative, there is a warm figure who can embrace all elements of employees at the factory of PT. KPA, and implements several types of styles in order to adapt to the situation in the field.
\end{abstract}

\section{KEY WORDS}

Human resources, leadership, loyalty, company.

Nowadays, with the increasingly rapid business development and the increasingly sharp competition level, the company must improve and develop its performance in all areas. Every company has a way of keeping its company maintained in the middle of a tight global competition. One of the areas that should continue to be leveled is Human Resources. Human resource is one of the most important assets in the development and achievement of the goals of an organization or a company. According to Hasibuan (2005), human resource management is "the science and the art of managing relationships and the role of labor to be effective and efficient, helping the realization of corporate, employee and community goals".

Talking about Human Resources, it will not be separated from leadership and employees because these two important elements have their respective roles in running a company. In a leadership, there is a leadership style that is expected to advance the company and the welfare of employees. Every leader has a different leadership behavior called a leadership style. A good leadership style is implemented to improve employee performance and to provide motivation to employees (Fatmawati, 2013). A good leader will not exist without a good subordinate, and vice versa. Both leaders and subordinates need each other to work together to make the company more advanced.

In general, the challenge of a leader not only focuses on the addition of productivity or employee work motivation, but also makes employees have a sense of loyalty to the company. It is because employee loyalty does not come by itself, but it takes the role of leaders and good management. According to Soegandhi and Sutanto (2013), loyalty will arise if a leader is able to maintain comfort in his work environment. Comfort is the result of policies issued and implemented within the work unit that he leads. It is reflected in the leadership style of an employer. Thus, it is very important for leaders to apply the right leadership style so that employee loyalty can be maintained.

However, it is not easy to grow a sense of employee's loyalty to the work they perform. The support from colleagues will help employees to improve their performance coupled with the support from leaders will help employees to remain loyal to the job (Full, 2013). At the present time, loyalty of the employees is not merely performing their duties and obligations as an employee in accordance with its job description, but doing the best possible to produce the best for the organization, (Soegandhi and Sutanto, 2013). Therefore, companies should be able to influence employee loyalty by providing job facilities, providing welfare benefits, and providing adequate wages (Martiwi et al., 2012). 
Employee loyalty is the most important and must be owned by every employee in the company or any agency. Based on research that has been done, A. Suyunus Adiwibowo (2012) states that companies need employees who have high loyalty because with the high loyalty of employees, the employees can work in accordance with the standards given by the company and can improve the quality of work. Low employee loyalty can result in reduced productivity, high absenteeism, and non-compliance of employees to their employers (Nitisemito, 1991). Then, it can lead to behavior that is contrary to company goals that can damage the vision and mission of the company.

This private company can be considered as a family company because its organizational structure and ownership involves family members. It is in accordance with the definition of Dictionary of Law (2002) as follows: Company where most of the shares are owned by members of the same family. In addition, according to Susanto (2005), Family Business Enterprise (or abbreviated as FBE) is a company owned and managed by family members of its founders. Both ownership and management are held by the same party, the family. Family company is characterized by the holding of key positions within the company by family members.

Taken from the data in the field, it is known that almost $64 \%$ of employees have been working in 10 years and $40 \%$ of employees have been working above 21 years. In this case, the majority of employees also feel the leadership of (Late) Mr. SHH - related to: the perceived leadership style of the first generation to the present, the things that drive them to remain loyal to the company, and their expectation for leadership style for the future. Thus, the criteria of informants, who will be excavated information, are the permanent employees of PT. KPA who have been serving over 10 years. The informants will be selected from the 11 working divisions in the company and family members of PT. KPA. It could be stated that PT. KPA is a pioneer and one of the oldest briquette factory in Surabaya area. In the future development, this family company needs reliable human resources and has the loyalty to compete with its competitors.

\section{METHODS OF RESEARCH}

This present research uses qualitative approach. Qualitative approach in this case is actually a research procedure that produces descriptive data in the form of written or oral words of people and behavior that can be observed. Therefore, the data collected is data in the form of words or sentences and images (not numbers). These data may include interview scripts, field notes, photographs, videos, personal documents, memos or other official documents (Moleong, 2005).

With this approach, the researcher can obtain a complete picture of the problem formulated by focusing on the process and searching the meaning behind the phenomenon that emerged in the research, with the hope that the information reviewed is more comprehensive, deeper, more natural and the way what it is. The subject of research in this research is the permanent employees of PT. KPA consisting of 11 divisions. The objects of research in this study include: (1) the first generation leadership style at PT. KPA; (2) the advantages and disadvantages of the first generation leadership at PT. KPA; and (3) the impact of the first generation leadership in the growth of human resource loyalty in PT. KPA.

Determination method of informant used in this research is purposive sampling. According to Sugiyono (2009), Purposive Sampling is a technique of sampling the source data with certain considerations, for example the person is considered most know about what is expected. The most important sampling procedure is how to determine a key informant or a particular social situation that is full of information. The basic key in Purposive Sampling is the mastery of information from the informant and logically that the key figures in the social process always directly control the information that occurs within the social process (Bungin, 2012). The use of Purposive Sampling in this research is aimed to know (1) how the leadership style of the first generation at PT. KPA, (2) what the advantages and the disadvantages of the first generation leadership at PT. KPA are, and (3) what the impact of 
the first generation leadership in the growth of human resource loyalty in PT. KPA is. In this study, the criteria of sampling of informants are as follows:

- The informants have status as permanent employees of PT. KPA;

- The informants are employees who belong to 11 divisions (Briquette, Oven-Charcoal, Packaging, Stuffing, Mechanical, General, Oven, Fire-Keeper, Security, PPC Leader, and Office Staffs (HRD, Marketing, Sales, Finance, Secretary));

- The informants have been serving over 10 years or have worked under the leadership of (Late) Mr. SHH;

- The informants have the status as a family member of the family company of PT. KPA.

The researcher uses two data sources to search and to collect data sources in this study and the results of data that will be processed namely: Primary Data and Secondary Data. The researcher uses several data collection techniques in this study namely: interview and observation.

The validity of data in qualitative research is as an attempt to increase the degree of data confidence. In qualitative research, the examination of the data validity is not only used to refute either the alleged unsatisfactory qualitative research, but also as an inseparable element of the body of qualitative research (Moleong, 2005).

The qualitative research of validity used is triangulation of data that utilizes something else outside the data for checking purposes or as a comparison towards the data (Moleong, 2005). Validity test through triangulation is done because to test the validity of data and information, it cannot be done with statistical tools. Similarly, the material of truth is not tested on the basis of the truth of the instrument, so that the substance of truth depends on an intersubjective truth. Therefore, something is assumed to be true if it represents the truth of the majority or the importance of stakeholders (Bungin, 2013). In this study, the triangulation method used by the research is through source checks. Comparing and re-checking the degree of confidence of information are obtained from different sources.

\section{RESULTS AND DISCUSSION}

The First Generation Leadership Style at PT. KPA. A company will experience a life cycle. There are four stages of organizational life cycle, namely: Birth, Growth, Decrease, and Death, (Jones, 1995).

Based on the theory, it can be understood that PT. KPA in the first stage namely growth through creativity, (Late) $\mathrm{SHH}$ develops new products to the market through the development of skills and capabilities so that the company can grow. In this case, there is a leadership crisis resulting from a managerial system that is not yet fully under way. Afterwards, PT. KPA during the first generation leadership also experiences the second stage; i.e. growth through directors. With the leadership crisis, (Late) $\mathrm{SHH}$ takes full responsibility and organizes corporate strategy. The structure in this phase is designed by top managers and centralizes decision-making and limits the freedom to experiment, take risks, and become an internal entrepreneur.

Theory of Organizational Life Cycle is supported by the results of interviews with informants who have done researchers. From the interviews with the informants, it is found that the leadership style by the first generation, (Late) Mr. SHH has 2 types of classification. There are some informants who state that Mr. SHH's figure is a populist, but there are also some informants who state that $\mathrm{Mr}$. $\mathrm{SHH}$ has an authoritarian leader figure. Several informants also use examples of prominent figure that they knew in which it is to illustrate the similarities to Mr. SHH's leadership style at PT. KPA. Thus, it can be understood that the style the first generation leadership of PT. KPA is a combination of Transformational Leadership Style, Entrepreneurship Leadership Style, and Authoritarian Leadership Style.

The Creation of a Sense of Kinship from the First Generation Leadership Period at PT. $K P A$. Developing family closeness like this can happen because (Late) $\mathrm{SHH}$ often introduces other members of his family to his employees. Especially when there is one member of his family who is celebrating birthday event, wedding, and so forth - $\mathrm{Mr}$. SHH often invites 
several employee representatives. Mr. SHH can create a close sense of kinship between employees because he is willing to mingle with all layers of the Human Resources element at PT. KPA both office staff and labor in the field. One of the ways he uses to cultivate family relationship is by inviting some employee representatives to attend family occasions, frequent meals, and being introduced to other family members. Thus, the feeling that employees also have a company is grown. It is presented by Mr. TC in the interview.

Mr. SHH's closeness as the leader of the company is also felt by the workers of PT. KPA. His concern for the workers is poured by providing pocket money and food when they work. Mrs. EV has a memory when Mr. SHH brought food directly to the back of the factory for the workers who were working in the night shift. Therefore, it can be known that (Late) Mr. $\mathrm{SHH}$ can create a close sense of kinship between employees because he is willing to mingle with all layers of the Human Resources element at PT. KPA starting from the workers to the office staff. Some of the ways used to strengthen family bonds are by inviting employees to attend family events, being introduced to other family members, often being invited to eat, and often brought food. Hence, the feeling that employees also have a company is there because employees think that (Late) $\mathrm{SHH}$ as a member of their own family, not as employer or superior.

The First Generation Leader as a Role Model. Some informants mention that (Late) Mr. $\mathrm{SHH}$ is a populist leader, a fighter who does not give up easily, cares about employees, and has a high sense of kinship. He wants to be a leader who can be a role model for his employees. Absolutely, with the kindness that he performs directly, it gives impact to all layers of employees. It is in accordance with the definition of Alrawabdeh (2014) which states that a charismatic leader is able to evoke powerful emotions. Leader is identified to be a role model by followers, trusted, respected, and have clear goals.

According to Pramudyo (2013), inspiring by modeling is the most effective way to exercise leadership and to influence the subordinates by making themselves leaders as models. The power of influence is determined by the ability to inspire subordinates through role modeling. Role modeling is manifested in two forms through passion and vision. Hence, it can be understood that the figure of (Late) $\mathrm{SHH}$ as the leader of the first generation and a role model for employees is the basic composition of his leadership. Mr. SHH has cultivated the leadership character and principles among his employees. This process of culture is done by internalizing the character and principles of leadership to all the subordinates so that they understand, live, and do it.

The Disadvantages of the First Generation Leadership Period at PT. KPA. According to informants, the shortcomings of the first generation of leadership at PT. KPA are somewhat egotistical, unclear job instruction, emotionally uncontrollable of $\mathrm{Mr}$. SHH when he is angry, more likely to listen to feedback from family members, and ignores suggestions from employees.

The Less Controlled Emotion of the First Generation Leader. The aspect of shortcoming felt by employees or family members from the period of leadership of the first generation at PT. KPA in majority is related to attitudes of (Late) $\mathrm{SHH}$ who sometimes if he is angry, he is less controlled and he says rude words. In addition, when problems occur, $\mathrm{Mr} \mathrm{SHH}$ also tends to listen to input from family members more than employees. It can happen because Mr. SHH is leader of a family company which with such behavioral trends will make employees feel unfair.

In this case, it is known that (Late) SHH, while serving as the leader of PT. KPA, has less stable emotions and tend to explode. This incident is most likely because of age, recurrence, anxiety, and stress, and side effect of medicine consumption. When there is a problem, Mr. SHH is also less able to listen to the input from the parties involved in it and tends to listen more to the advice of the family only. This is because PT. KPA is a family company and $\mathrm{Mr}$. $\mathrm{SHH}$, as the first generation leader, puts more trust in the second generation.

The Less Working Leadership Function and Managerial System in the First Generation Leadership Period of PT. KPA. Mr. JIN, the Finance Director of PT. KPA, states that (Late) 
$\mathrm{SHH}$ has a tendency for one-man-show because the educational background is the graduate of fifth grade of elementary school and he is lack of the overall managerial system.

Mr. SHH's unclear work instruction and speech are sometimes stuttering, leaving employees confused and vulnerable to mistakes. In this case, the delivery of instructions that are not clear by Mr. SHH is influenced by the age factor which is old.

Based on the facts, Mr. SHH tends to less run the proper leadership function. According to Veithzal (2005), there are five leadership functions, namely: Instructive Function, Consultative Function, Participation Function, Delegation Function, and Control Function. In this case, the leadership of the first generation is less able to implement instructive and consultative function. Instructive function is somewhat hampered because Mr. $\mathrm{SHH}$ as a leader and a communicator cannot deliver the instruction work orders well and clear. Then, the consultative function cannot be implemented properly because $\mathrm{Mr}$. $\mathrm{SHH}$ is less able to listen to employees' input as a consideration in decision making.

In addition, Mr. SHH is unable to implement an effective managerial system. It is because he applies the traditional management system and focuses more on $\mathrm{Mr}$. SHH himself. This focus on individual performance leads to fragmented work in the hierarchical system (Suhartono, 2010). The existence of the focus on individual performance also results in performance management feedback which also comes from one source only that is from employer. The first generation managerial system is too focused on separate administrative practices, which in turn; it frequently leads to different problems and does not have clear objective goals between one another.

The Strict and Authoritative Attitude of the First Generation Leader. According to some informants, Mr. SHH also has a harsh character, so that if he wants something - he will insist on doing so. Selfishness in this regard is related to the attitude of $\mathrm{Mr}$. SHH who often ignores suggestions from employees and tends to be one-man-show. Based on the results of interviews, some informants mention that Mr. SHH's selfish attitude often makes them inconvenient because sometimes what he wants is not rational. Absolute decision-making is performed by Mr. SHH without considering the factors that exist in the field. In accordance with the leadership function Veithzal (2005), consultative function cannot be realized properly because $\mathrm{Mr}$. $\mathrm{SHH}$ is less able to listen to employee input as a consideration in decision making. Decision-making is only self-defined by $\mathrm{Mr}$. $\mathrm{SHH}$; subordinates are excluded from providing suggestions, ideas, and considerations in the decision-making process. Leadership orientation is focused only to increase employee productivity with less attention to the feeling and the welfare of subordinates (Hasibuan, 2007).

The Impact of the First Generation Leadership in the Growth of Human Resources Loyalty at PT. KPA. Loyalty is an asset to the company. Loyalty will arise if a leader is able to maintain comfort in his work environment. Comfort is the result of policies issued and implemented within the work unit that he leads. It is reflected in the leadership style of an employer. According to the journal of 'Relationship Leadership with Employee Loyalty to Superiors in HR Group PT. Bank DKI' (Wisesa, 2008), there is a real, positive, and strong correlation between leadership and employee loyalty of HR group of PT. Bank DKI. Thus, it is very important for leaders to apply the right leadership style so that employee loyalty can be maintained.

Based on the results of research that has been done, the leadership of the first generation has a significant impact on the loyalty growth of human resources in PT. KPA Surabaya. It is indicated by the existence of data in the field which is known that almost $64 \%$ of employees have been working in 10 years and $40 \%$ of employees have been working over 21 years. According to 'How Employee's Loyalty Programs Impact Organizational Performance within Jordanian Banks?', employee loyalty is not merely in form of physical loyalty or existence in an organization, but it includes thoughts, concerns, ideas, and dedication provided entirely to the organization. $\mathrm{Mr}$. $\mathrm{SHH}$ as the leader of the first generation affects employee loyalty by creating a sense of satisfaction, financial reward, work motivation, performance appraisal, training, and a conducive working environment. Therefore, it can be known that the leadership of Mr. SHH gives a significant impact on the 
loyalty growth with the fulfillment of aspects of loyalty in the employees and human resources of PT. KPA.

The Aspect of Obedience or Compliance on Human Resources of PT. KPA. According to Saydam (2000), the aspect of obedience is defined as the ability of an employee to obey all applicable official regulations and obey the official orders given by superiors who are authorized, and able not to violate the prescribed restrictions. In this case, the aspect of obedience to human resources of PT. KPA during the first generation of leadership is very high because the employees of PT. KPA are reluctant to the figure of (Late) Mr. SHH as the leader. The figure of (Late) $\mathrm{SHH}$ as a leader and a good role model become the holistic model illustration for employees of PT. KPA to always provide the best service for the company. He himself as a leader is able to apply his compliance or obedience to company regulations. A simple example is to come and to go home from work on time. It can be felt until now that all employees of PT. KPA are obedient to company regulations.

The Aspect of Accountability on Human Resources of PT. KPA. The aspect of accountability is the ability of an employee to complete the work submitted to him well, on time, and dare to take risks for decisions made or actions taken (Saydam, 2000). In PT. KPA, it is reflected that during the first generation leadership - employees have a sense of responsibility in the company. One of the informants, FSD, who has been working for 18 years at PT. KPA state that she is often moved in some division works while working in this family company. However, she is still willing to be placed in any division; FSD still reflects her sense of responsibility on the job given by the employer. Therefore, it can be understood that employees of PT. KPA has reflected the characteristics of a responsible employee to the company because (Late) SHH often gives advice to the employees. In addition, he implements this high sense of responsibility by becoming a real example for every employee. $\mathrm{He}$ is responsible for the company both when the company experiences an increase and decrease. He always gives the best for the progress of PT. KPA. It can be felt until now that all employees of PT. KPA have high mrale and accountability for every job done.

The Aspect of Honesty on Human Resources of PT. KPA. The aspect of honesty in general is the harmony between the spoken or the deed and the reality (Saydam, 2000). There is one memorable moment that FSD cannot forget while working during the first generation leadership related to the issue of honesty. With a strict character of (Late) Mr. $\mathrm{SHH}$, he does not tolerate any problems related to dishonesty to work. In that case, Mr. SHH immediately calls the police to check on something suspicious. This encourages employees to always be honest by always doing the task with full sincerity, not abusing the existing authority, reporting the work to the employer as it is, and do not cover the mistakes of work that has been done.

The Aspect of Dedication on Human Resources of PT. KPA. According to the majority of informants, they as employees of PT.KPA have contributed thought and energy to the company because of the factors from the leadership of the first generation itself. The growth of dedication aspect on human resources of PT. KPA is inseparable from the leader figure of (Late) SHH which reflects his great dedication while still active in work or in sick condition for the sustainability of PT. KPA. According to an informant namely Mr. TC, he claims to be able to learn many things from the leadership of (Late) SHH. Mr. TC as a financial officer who has been working for 26 years admits that his life motto can be found on the $\mathrm{SHH}$ figure which is about always sharing with others. Although (Late) $\mathrm{SHH}$ is gone, the leadership of the first generation has an impact in the growth of familial relationships that can be felt to this day. One example is the creation of a very close relationship between (Late) $\mathrm{SHH}$ with its employees. SHH often invites his employees to join a meal together and to be introduced to other family members. With the formation of such a work environment, Mr. TC admits to feel the company.

Hence, it can be known that the employees of PT. KPA have the characteristics of employees who have aspects of good self-service because they have the desire to work hard and the effort to maintain position because they feel it as the parts of the company; believe and trust the values that exist in the organization and apply it to yourself, and willing to work on the company for a long time. It is supported by field data indicating that nearly $64 \%$ of 
employees have been working over 10 years and $40 \%$ of employees have been working over 21 years.

\section{CONCLUSION}

The thesis research that discusses the Impact of the First Generation Leadership in the Growth of Human Resources Loyalty of PT. KPA has produced the following conclusions:

The leadership style of (Late) SHH is a combination of Transformational Leadership Style, Entrepreneurship Leadership Style, and Authoritarian Leadership Style. In Mr. SHH's strict and authoritarian personality, there is a warm figure who can embrace all elements of employees at the factory of PT. KPA. Mr. SHH, as a leader and also a role model, wants to create a sense of shyness towards employees, not a fear of the leader. It can happen due to the fact that Human Resources of PT.KPA consist of various families and educational backgrounds. Hence, Mr. SHH implements several types of styles in order to adapt to the situation in the field because a responsible leader will understand which leadership style is appropriate and right to apply in his company.

The advantages had by the leadership of the first generation are a sense of close family, populist, high social spirit, and want to go to the field directly. The disadvantages of the first generation leadership are somewhat egotistical, unclear job instruction, emotionally overwhelmed, more likely to listen to feedback from family members, and ignore suggestions from employees.

(Late) $\mathrm{SHH}$ as the leader of the first generation affects employee loyalty by creating a sense of satisfaction, giving financial rewards, working motivation, performance appraisal, training, and working environment.

The impact of the first generation leadership style encourages the growth of loyalty aspect of PT.KPA among others: aspect of obedience or compliance, aspect of accountability, aspect of honesty, and aspect of dedication.

The first generation leadership style has a significant impact in the growth of human resources loyalty of PT. KPA.

\section{REFERENCES}

1. Adiwibowo, S. (2012) 'Kepemimpinan dan Loyalitas Terhadap Kinerja Karyawan RSJ Menur Surabaya', Jurnal Manajemen Bisnis, Vol 2, No. 01, Edisi April 2012.

2. Alrawabdeh, W. (2014) 'How Employees' Loyalty Programs Impact Organizational Performance within Jordanian Banks?', Canadian Center of Science and Education : International Business Research, Vol. 7, No. 9.

3. Bungin, B. (2012) Analisis Data Penelitian Kualitatif. Jakarta: Raja Grafindo Persada.

4. Bungin, B. (2013) Metodologi Penelitian Sosial \& Ekonomi. Jakarta: Kencana Prenada Media.

5. Fatmawati, S. (2013) 'Pengaruh Gaya Kepemimpinan Terhadap Kinerja Karyawan Pada Kebun Rimba Belian Inti Kabupaten Sanggau', Program Studi Ilmu Administrasi Negara, Fakultas IImu Sosial dan IImu Politik, Universitas Tanjungpura, Pontianak.

6. Hasibuan, M. S. P. (2005) Manajemen Sumber Daya Manusia. Jakarta: PT. Bumi Aksara.

7. Hasibuan, M. S. P. (2007) Manajemen Sumber Daya Manusia. Jakarta: PT. Bumi Aksara.

8. Jones, G. R. (1995) Organizational Theory Text and Cases. Amerika : Addison- Wesley Publishing Company.

9. Martiwi, R.T., Triyono, \& Mardalis, A. (2012) 'Faktor-Faktor Penentu Yang Mempengaruhi Loyalitas Pekerja', Daya Saing Jurnal Ekonomi Manajemen Sumber Daya, 13 (1), 44-52.

10. Moleong, L. J. (2005) Metodologi Penelitian Kualitatif. Bandung: Remaja Rosdakarya.

11. Nitisemito, A. S. (1991) Manajemen Personalia: Manajemen Sumber Daya Manusia. Jakarta: Ghalia Indonesia. 
12. Pramudyo, A. (2013) 'Implementasi Manajemen Kepemimpinan dalam Pencapaian Tujuan Organisasi'. Jurnal JBMA, Vol. 1, No. 2.

13. Purnama, A. (2013). Peranan Gaya Kepemimpinan Dan Sistem Pengendalian Manajemen Terhadap Loyalitas Karyawan Di Perusahaan Keluarga PT. SUS Surabaya. Calyptra, 2(2), 1-17.

14. Saydam, G. (2000) Manajemen Sumber Daya Manusia (Human Resource) Suatu Pendekatan Mikro. Jakarta: Djanbatan.

15. Soegandhi, V., \& Sutanto, E. M. (2013). Pengaruh kepuasan kerja dan loyalitas kerja terhadap organizational citizenship behavior pada karyawan PT. Surya Timur Sakti Jatim. Agora.

16. Sugiyono. (2009) Metode Penelitian Bisnis (Pendekatan Kuantitatif, Kualitatif, dan R\&D). Bandung: Alfabeta.

17. Suhartono, I. (2010) 'Manajemen Kinerja pada Perusahaan Bisnis dari Manajemen Kinerja Tradisional ke Manajemen Kinerja Baru', Jurnal Among Makarti, Vol. 3, No. 5.

18. Susanto, A. B. (2005) World Class Family Business. Jakarta: Quantum Bisnis.

19. Veithzal, R. (2005) Manajemen Sumber Daya Manusia. Jakarta: Raja Grafindo Persada.

20. Wisesa, R. (2008) "Hubungan Kepemimpinan dengan Loyalitas Karyawan pada Atasan pada Grup SDM PT. Bank DKI', Departemen Manajemen, Fakultas Ekonomi dan Manajemen, Institut Pertanian Bogor. 